\title{
The relative effects of a low-protein-high-carbohydrate diet on the free amino acid composition of liver and muscle
}

\author{
By P. G. LUNN, R. G. WHITEHEAD AND B. A. BAKER \\ Medical Research Council, Dunn Nutritional Laboratories, \\ Milton Road, Cambridge $\mathrm{CB}_{4}$ I $X \mathcal{Y}$
}

(Received 3 November 1975 - Accepted 29 fanuary 1976)

\begin{abstract}
I. Free amino acid concentrations in the plasma have been compared with those in liver and quadriceps muscle, in rats fed on diets containing 209 (control) and $3 \mathrm{I}$ (low-protein) $\mathrm{g}$ protein $/ \mathrm{kg}$. The effects of the low-protein diet on diurnal variations in these values were also measured.

2. In the plasma, the total amino acid concentration was significantly lower in animals given the low-protein diet, at all times of day except 12.00 hours. In the liver, and to a lesser extent the muscle, total amino acid concentration was maintained.

3. In the control animals, diurnal variation in the concentrations of both essential and nonessential amino acids was very similar in plasma, liver and muscle. In animals given the lowprotein diet, although the same diurnal pattern was maintained for non-essential amino acids, that occurring among the essential amino acids had virtually disappeared.

4. In plasma, the mean $24 \mathrm{~h}$ concentration of essential amino acids decreased from 2.43 $\mathrm{mmol} / \mathrm{l}$ in control animals to only $\mathrm{r} .29 \mathrm{mmol} / \mathrm{l}$ in the low-protein-fed animals. Concentrations in muscle and liver were reduced by a similar proportion (from 8.60 to $5.56 \mu \mathrm{mol} / \mathrm{g}$ and from 8.67 to $5.05 \mu \mathrm{mol} / \mathrm{g}$ respectively). Conversely the concentrations of non-essential amino acids in animals given the low-protein diet were increased in plasma (from 1.53 to $2.00 \mathrm{mmol} / \mathrm{l}$ ), muscle (from 12.5 to $14.3 \mu \mathrm{mol} / \mathrm{g}$ ), and liver (from 16.8 to $20.5 \mu \mathrm{mol} / \mathrm{g}$ ), muscle showing the lowest increase.

5. With the exceptions of lysine, threonine, cystine and tyrosine, the concentrations of all other essential amino acids were reduced more in liver than in muscle. The relationship between this and the failure to maintain plasma albumin concentrations is discussed.
\end{abstract}

Changes in the pattern of free amino acids in the plasma of children with kwashiorkor and in protein-deficient animals are well documented and have been reviewed by Waterlow \& Alleyne (1971). Basically, the concentrations of most essential amino acids are reduced, and the non-essential ones are present in either normal or increased amounts. It has been postulated (Whitehead \& Alleyne, 1972; Lunn, Whitehead, Hay \& Baker, I973; Rao, 1974) that the low plasma concentrations of the essential amino acids are partly due to an inadequate dietary intake relative to requirements, and are partly the result of a selective shunting of amino acids out of the plasma into muscle. It was suggested that as a result the liver might become disproportionately deprived of essential amino acids. It was important to establish this last point because it could be a reason for the low rate of synthesis, and the low concentration of plasma albumin in kwashiorkor (Kirsch, Saunders, Frith, Wicht, Kelman \& Brock, I969).

Whether or not the concentrations of essential amino acids in the liver are especially affected in this way has been questioned, however. Munro (1970), for example, has pointed out that while there is often a close association between changes in the free amino acid composition in plasma and muscle, liver can behave differently. This occurs for two reasons. First, the liver proteins are capable of large changes in turn- 
Table 1. Composition of the control and low-protein diets given to rats

\begin{tabular}{lcc}
\multicolumn{1}{c}{ Constituent $(\mathrm{g})$} & Control & Low-protein \\
Casein & 210 & $31 \cdot 5$ \\
Cystine & 3 & $0 \cdot 45$ \\
Sucrose & 355 & $444 \cdot 5$ \\
Starch & 355 & $444 \cdot 5$ \\
Maize oil & 30 & 30 \\
Salt mixture* & 50 & 50 \\
Total & 1003 & 1001 \\
B-vitamin and choline & I0 & 10 \\
chloride mixture (ml $/ \mathrm{kg}) \dagger$ & & \\
Fat-soluble vitamin mixture + & I dose $/$ week & 1 dose $/$ week \\
Energy content $(\mathrm{MJ} / \mathrm{kg})$ & $16 \cdot 70$ & $16 \cdot 70$ \\
Carbohydrate $(\mathrm{g} / \mathrm{kg})$ & 701 & 879 \\
Protein $(\mathrm{g} / \mathrm{kg})$ & 209 & 31
\end{tabular}

- Containing $(\mathrm{g} / \mathrm{kg})$ : calcium carbonate 205 , calcium hydrogen phosphate 325 , disodium hydrogen phosphate 185 , potassium chloride 205 , magnesium sulphate 4.5 , ferric citrate 4.35 , copper sulphate 0.375 , zinc carbonate 0.75 , potassium iodate 0.025 . (Commercially prepared by Arthur $\mathrm{H}$. Cox, Brighton, as recommended by Williams \& Briggs (1963).)

† Containing: choline chloride $2 \mathrm{~g}$, calcium pantothenate $20 \mathrm{mg}$, thiamin $3 \mathrm{mg}$, pyridoxine $3 \mathrm{mg}$, riboflavin $3 \mathrm{mg}$, nicotinamide $25 \mathrm{mg}$, biotin $0.1 \mathrm{mg}$, cyanocobalamin $0.05 \mathrm{mg}$; the mixture was made up to $10 \mathrm{ml}$ with water and added to $\mathrm{I} \mathrm{kg}$ of each diet.

$\ddagger$ Each rat received weekly doses of fat-soluble vitamins in arachis oil: retinyl acetate $344 \mu \mathrm{g}$, ergocalciferol $5 \mu \mathrm{g}$, DL- $\alpha$-tocopheryl acetate $2 \mathrm{mg}, 2$-methyl-I 4 -naphthoquinone $0.05 \mathrm{mg}$.

over rate and the endogenous amino acids thus released provide a major part of the free amino acid pool of this organ. Secondly, amino acids from the diet first move to the liver, which again might buffer this organ from amino acid depletion.

The purpose of this study therefore was to determine the extent to which the changes in the plasma amino acid pattern induced by feeding rats on a low-proteinhigh-carbohydrate diet also occurred in the free amino acid pools of liver and muscle, and whether liver was affected to a greater or lesser extent than muscle. Since Young, Vilaire, Newberne \& Wilson (I973) have reported the importance of diurnal variation in the interpretation of plasma amino acid patterns, in the present study animals were sampled throughout a $24 \mathrm{~h}$ period, not just taking the usual fasting sample.

\section{EXPERIMENTAL}

Males from an inbred, specific-pathogen-free strain of hooded rats were used in the experiment. The animals were weaned at 3 weeks onto a synthetic diet containing $2 \mathrm{rog}$ casein $/ \mathrm{kg}$ (control) and supplemented with cystine. After I week, half the animals were transferred onto an isoenergetic diet containing only $3^{1} \cdot 5 \mathrm{~g}$ casein $/ \mathrm{kg}$ (low-protein). Animals were given the control or low-protein diets ad lib. for a further I4 d. Details of the diets are given in Table 1.

At the end of this period, five rats from each dietary treatment group were killed at I 5.00 hours and then for each dietary treatment further groups of five were killed at intervals of $3 \mathrm{~h}$ thereafter until 12.00 hours the next day. Before slaughter they were anaesthetized with Nembutal (Abbott Laboratories Ltd, Queenborough, Kent) and blood was collected by cardiac puncture into heparinized tubes. Approximately 
Table 2. Food intakes of rats given diets containing either 209 (control) or 3 I (low-protein) g protein $/ \mathrm{kg}$

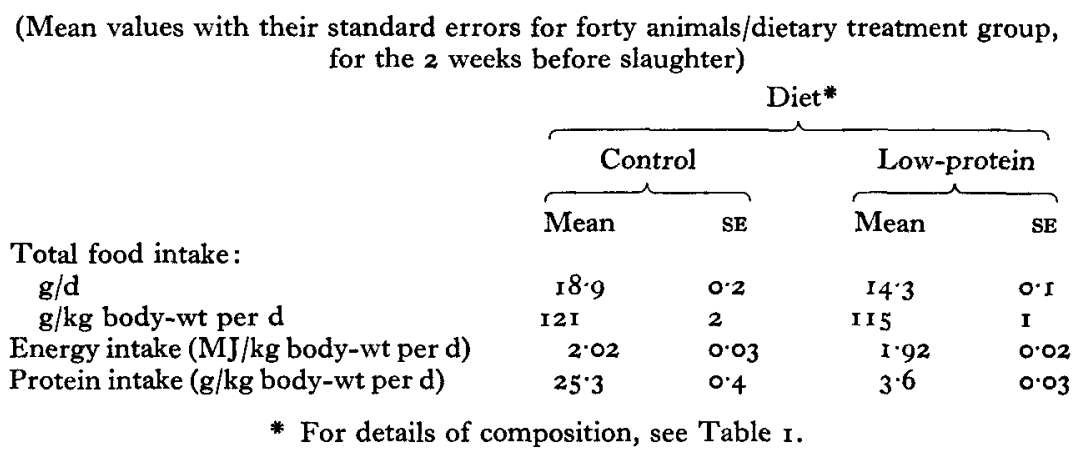

I $\mathrm{g}$ of both liver and quadriceps muscle was removed, weighed, chopped and placed in $10 \mathrm{ml}$ trichloroacetic acid ( $100 \mathrm{~g} / \mathrm{l}$ ). The tissues were homogenized and the supernatant fraction containing the free amino acids was removed after centrifugation. These tissue extracts together with the plasma were stored at $-20^{\circ}$ until they could be analysed.

Amino acids were estimated using an amino-acid analyser (TSM AutoAnalyzer; Technicon Instruments Co. Ltd, Basingstoke, Hants) fitted with an automatic integrator (model CRS-210; Infotronics (UK) Ltd, Wantage, Oxon.). An AutoAnalyzer programme which took $92 \mathrm{~min}$ was used, and the integrator allowed accurate direct estimation of the amino acid concentrations even in the tissues where there were extremely large differences between individual amino acids.

Serum albumin was measured using an automated dye-binding procedure employing bromocresol green (Northam \& Widdowson, 1967).

\section{RESULTS}

\section{Food intake and growth rates}

Food intake was measured daily, and mean values are given in Table 2. Although over-all energy intakes were lower in the experimental group than in the control animals, expressed on a $/ \mathrm{kg}$ body-weight basis they were not dissimilar. It is therefore reasonable to assume that the reduced growth rates of the rats given the low-protein $\operatorname{diet}$ (Fig. I) were due more to protein than energy deficiency.

In animals given the low-protein diet for 2 weeks serum albumin concentrations decreased from 354 to $306 \mathrm{~g} / 1(P<0.00 \mathrm{I})$, whereas in control animals there was an increase from 354 to $367 \mathrm{~g} /$, which was not statistically significant.

\section{Diurnal variations in amino acid concentration}

Although each amino acid in the plasma, liver and muscle of the control animals showed some individual variation in diurnal rhythm, the general trends were the 


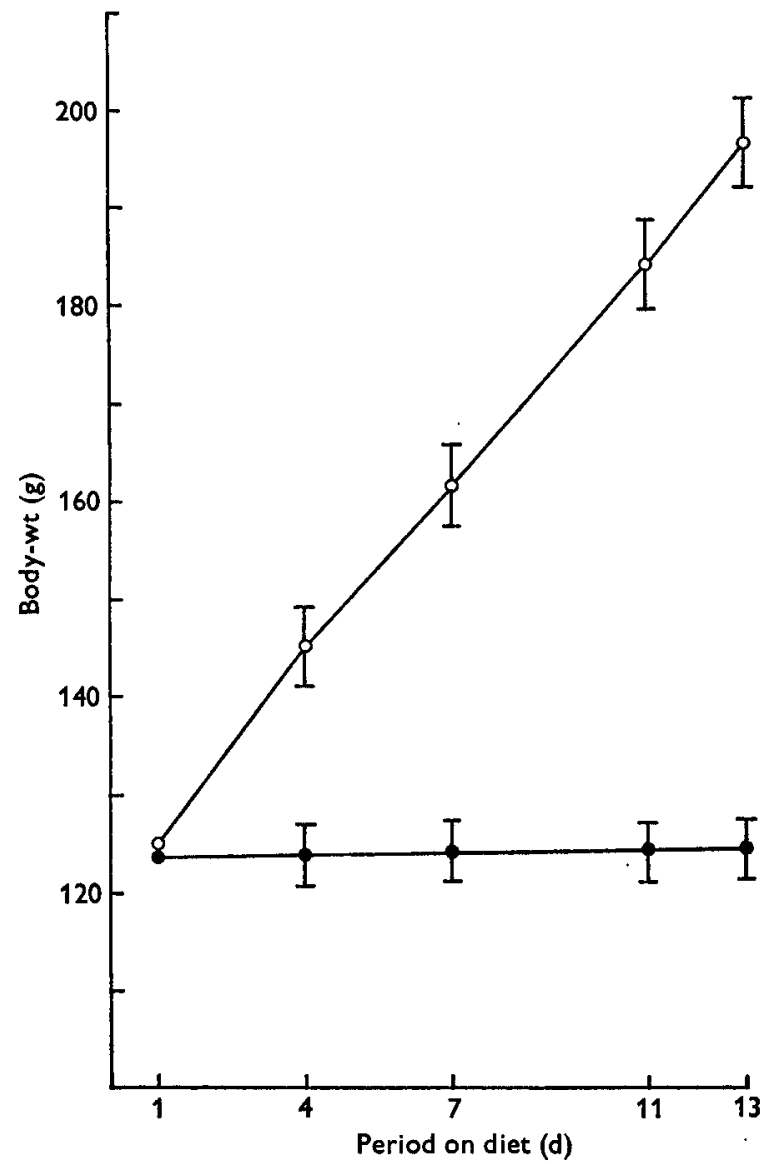

Fig. I. Growth rates of rats given a control diet containing $209 \mathrm{~g}$ protein $/ \mathrm{kg}(\mathrm{O})$, or a lowprotein diet containing $3 \mathrm{I} \mathrm{g}$ protein $/ \mathrm{kg}(\mathcal{O})$; for details of diets, see Table $\mathrm{I}$. Points are mean values with their standard errors for forty animals/dietary treatment group.

same. These patterns and the changes brought about by the low-protein diet are shown in Figs. 2, 3 and 4 .

Plasma. Total plasma amino acid concentration in the control animals varied during the $24 \mathrm{~h}$ cycle (Fig. 2); it was low at 21.00 hours and high at 06.00 hours. In the lowprotein group, this diurnal variation was to a large extent absent; at 06.00 hours for example, there was an actual decrease in concentration. Except at 12.00 hours total amino acid concentration was always lower in the animals given the low-protein diet, and the mean difference throughout the day was $17.5 \%(P<0.001$, Table 3$)$.

The diurnal variations in the plasma non-essential and essential groups of amino acids in the control animals were similar, but they differed markedly from those of the low-protein group. The concentration of essential amino acids was very much reduced in these animals at all times during the $24 \mathrm{~h}$ period, the mean decrease compared to control animals being $47 \%(P<0.001)$, whereas the non-essential amino acid concentration was increased $(P<0.00 \mathrm{I})$ throughout by an average of $30 \%$ (Table 3). 


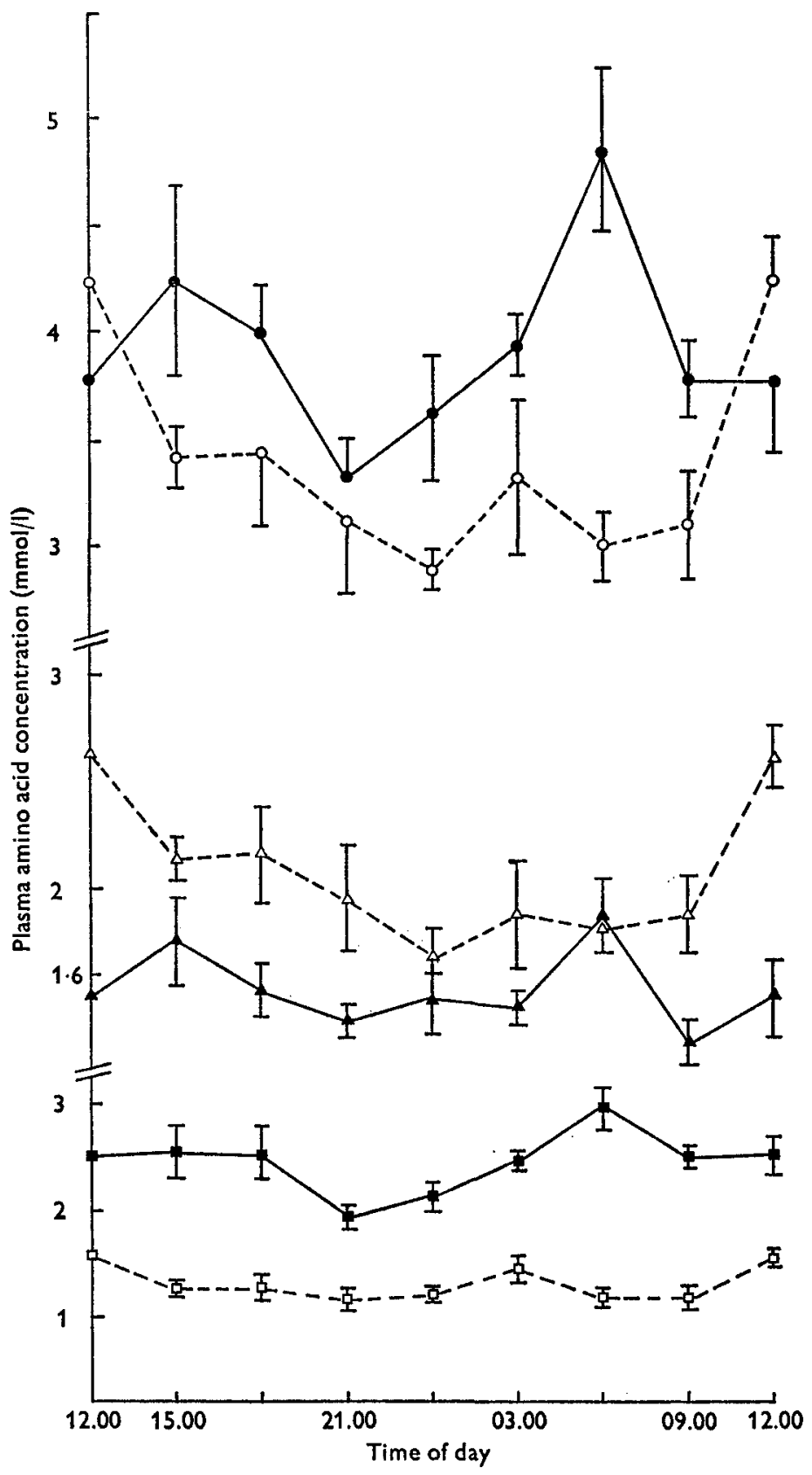

Fig. 2. Diurnal variation in plasma amino acid concentration $(\mu \mathrm{mol} / 1)$ in rats given for $14 \mathrm{~d} \mathrm{a}$ control diet containing $209 \mathrm{~g}$ protein $/ \mathrm{kg}: O$, total; $\Delta$, non-essential; $\boldsymbol{\square}$, essential; and in rats given a low-protein diet containing $3 \mathrm{I}$ g protein $/ \mathrm{kg}: O$, total; $\triangle$, non-essential; $\square$, essential. Points are mean values with their standard errors for five animals for each dietary treatment; groups of five animals were killed at I $_{5} .00$ hours, then at $3 \mathrm{~h}$ intervals until 12.00 hours the next day. For details of diets, see Table 1 . 
Table 3. Changes in essential, non-essential and total amino acid concentrations in plasma (mmol/l), quadriceps muscle and liver ( 4 mol/g) of rats given diets containing either 209 (control) 3 I (low-protein) $g$ protein $/ \mathrm{kg}$ for I4 $d$

(Mean values with their standard errors for forty animals/dietary treatment group for the $24 \mathrm{~h}$ study period)

Amino acids $\ldots$

$\begin{array}{llrc} & \text { Diet* } & \overbrace{\text { Mean }} & \text { SE }\end{array}$ P†

\begin{tabular}{|c|c|c|c|c|c|}
\hline \multicolumn{2}{|c|}{ Essential } & \multirow[b]{2}{*}{$P \uparrow$} & \multicolumn{2}{|c|}{ Non-essential } & \multirow[b]{2}{*}{$P \dagger$} \\
\hline Mean & SE & & Mean & $\mathrm{SE}$ & \\
\hline $2 \cdot 42$ & $0.08)$ & & & 0.05 & \\
\hline$I \cdot 29$ & 0.04 & & $2 \cdot 00$ & $0.07 \mathrm{~J}$ & \\
\hline $8 \cdot 60$ & $0.23)$ & $<0.001$ & 12.54 & & \\
\hline $5 \cdot 56$ & 0.12 & & $14 \cdot 34$ & 0.28 & \\
\hline $8 \cdot 67$ & 0.251 & $<0.001$ & $16 \cdot 77$ & 0.45 & \\
\hline $5^{\circ} \circ 5$ & $0.13\}$ & & & $0.53\}$ & \\
\hline
\end{tabular}

NS, not significant.

* For details of composition, see Table $\mathrm{I}$.

+ Statistical significance of difference between dietary treatments ( $t$ test).

Muscle. Total free amino acid concentrations in the muscle of control animals showed less diurnal variation (Fig. 3 ) than the corresponding plasma values, furthermore there was only a slight difference both in diurnal variation and concentration between control and low-protein-fed animals, the mean reduction being only $6.3 \%$ $(P<0.01)$.

As a group, the essential amino acid concentration in the control muscle showed a variation similar to that of the total amino acids, with peaks at 15.00 and 09.00 hours In the low-protein-fed animals the diurnal variations in essential amino acids had virtually disappeared, and their over-all concentration was reduced, although not quite so much as in the plasma, by an average of $35 \%(P<0.001)$.

Concentrations of non-essential amino acids in both groups of animals showed similar diurnal variations. Again the concentrations were somewhat higher in the low-protein group but the mean daily increase was only $14.4 \%(P<0.00 \mathrm{I})$, much less than the corresponding increase in the plasma.

Liver. Mean total free amino acid concentrations in this tissues did not differ significantly between control and low-protein-fed animals (Table 3). There was also a well-pronounced diurnal variation in both groups of animals (Fig. 4).

The concentration of essential amino acids, however, showed little diurnal variation even in the control animals, and this disappeared completely in the low-protein-fed. animals, in which the mean concentration of essential amino acids was substantially reduced $(4 \mathrm{I} \cdot 7 \%, P<0.00 \mathrm{I})$. The concentration of non-essential amino acids was increased by $22.4 \%,(P<0.001)$, but the diurnal variation was very similar to that in the controls. 


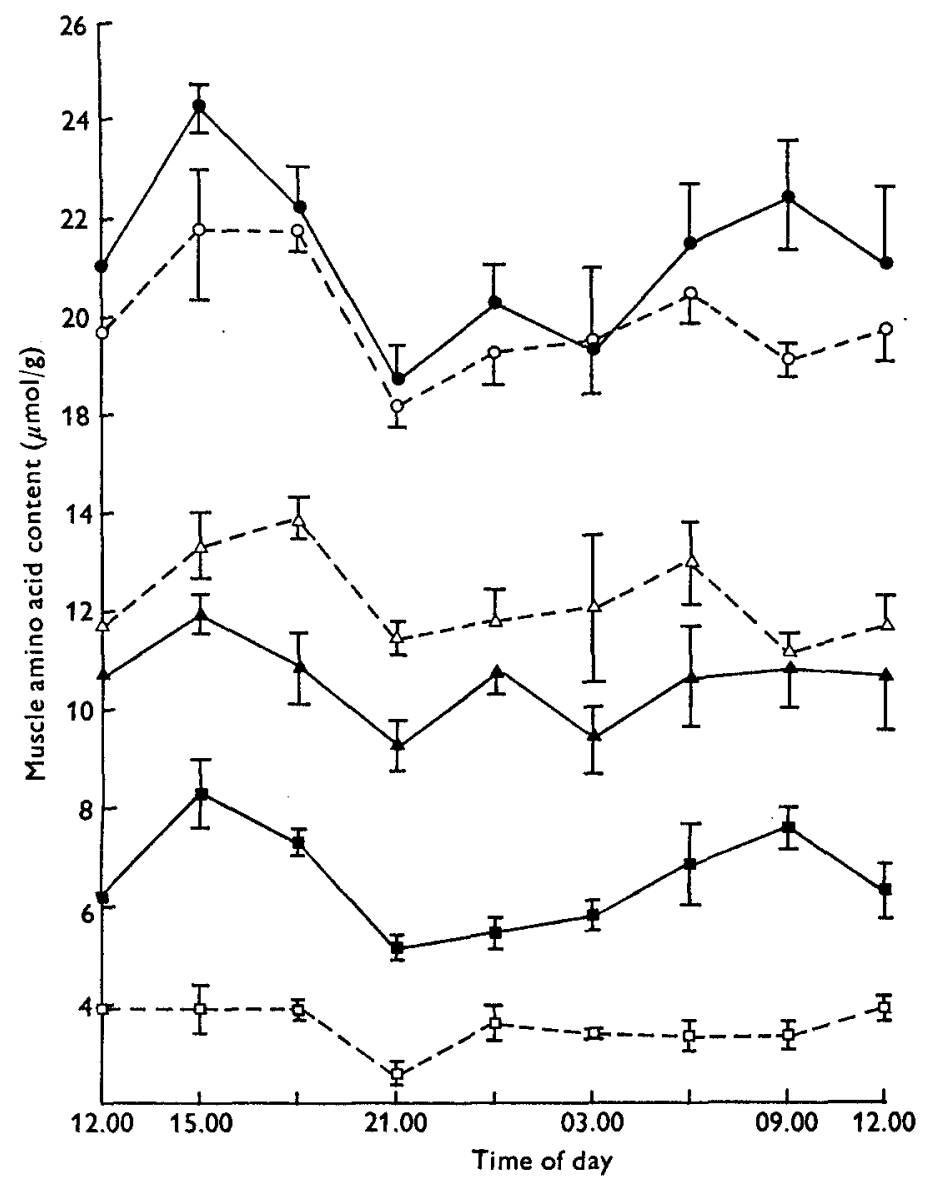

Fig. 3. Diurnal variation in quadriceps muscle amino acid content $(\mu \mathrm{mol} / \mathrm{g})$ in rats given for I $4 \mathrm{~d}$ a control diet containing $209 \mathrm{~g}$ protein $/ \mathrm{kg}:-$, total; $\boldsymbol{\Lambda}$, non-essential; $\mathbf{\square}$, essential; and in rats given a low-protein diet containing $31 \mathrm{~g}$ protein $/ \mathrm{kg}: O$, total; $\triangle$, non-essential; $\square$, essential. Points are mean values with their standard errors for five animals for each dietary treatment; groups of five animals were killed at 15.00 hours, then at $3 \mathrm{~h}$ intervals until 12.00 hours the next day. For details of diets, see Table $\mathrm{r}$.

\section{Individual amino acids}

The analysis of groups of amino acids indicated the general changes, but some amino acids were affected more than others. Table 4 gives the mean concentrations for each amino acid throughout the day in both the control and low-protein-fed animals.

Among the essential amino acids, concentration of lysine, threonine, cystine, valine, isoleucine, leucine, tyrosine and phenylalanine were lower in all tissues. Histidine concentration only showed a marked reduction in the liver, and that of methionine was only markedly reduced in the plasma. Of the non-essential amino acids, aspartic acid and glutamine plus glutamic acid concentrations were affected least. Proline concentrations were much reduced and those of serine increased in all tissues. Alanine was greatly increased in concentration in plasma and liver but only slightly in muscle, 


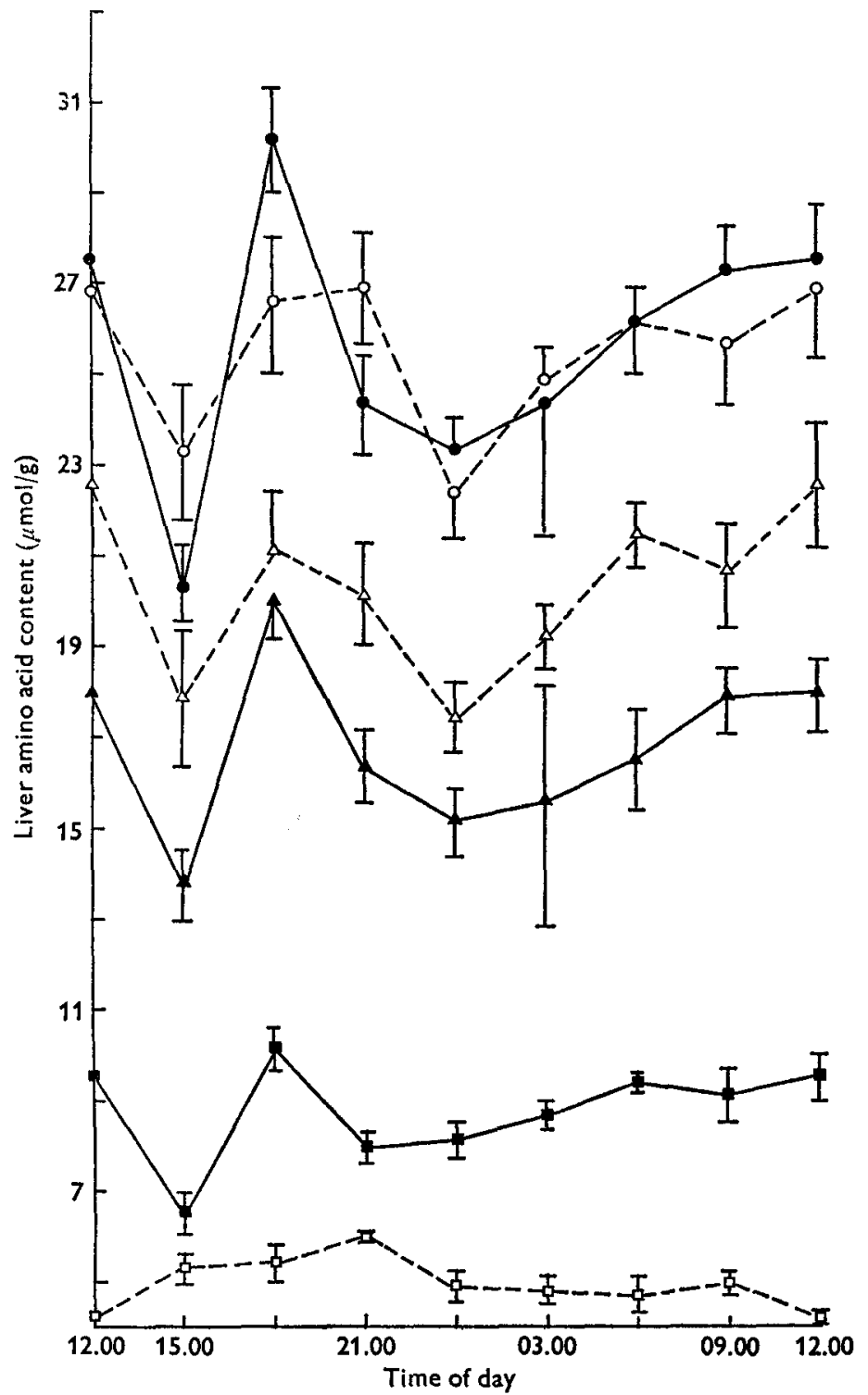

Fig. 4. Diurnal variation in liver amino acid content $(\mu \mathrm{mol} / \mathrm{g})$ in rats given for $14 \mathrm{~d}$ a control diet containing $209 \mathrm{~g}$ protein $/ \mathrm{kg}: \boldsymbol{O}$, total; $\boldsymbol{\Lambda}$, non-essential; $\boldsymbol{\square}$, essential; and in rats given a low-protein dietc ontaining $31 \mathrm{~g}$ protein $/ \mathrm{kg}$ : $\bigcirc$, total; $\triangle$, non-essential; $\square$, essential. Points are mean values with their standard errors for five animals for each dietary treatment; groups of five animals were killed at 15.00 hours, then at $3 \mathrm{~h}$ intervals until 12.00 hours the next day. For details of diets, see Table I.

whereas glycine was increased in muscle and plasma, but not in liver. In plasma, concentrations of cystine, valine, isoleucine, leucine and tyrosine were less than $50 \%$ of control values. Because of the reduced diurnal variation in amino acid patterns, at certain times of day the reduction below control values in the low-protein-fed animals was much greater than is indicated by the mean reduction; for example at 06.00 hours 


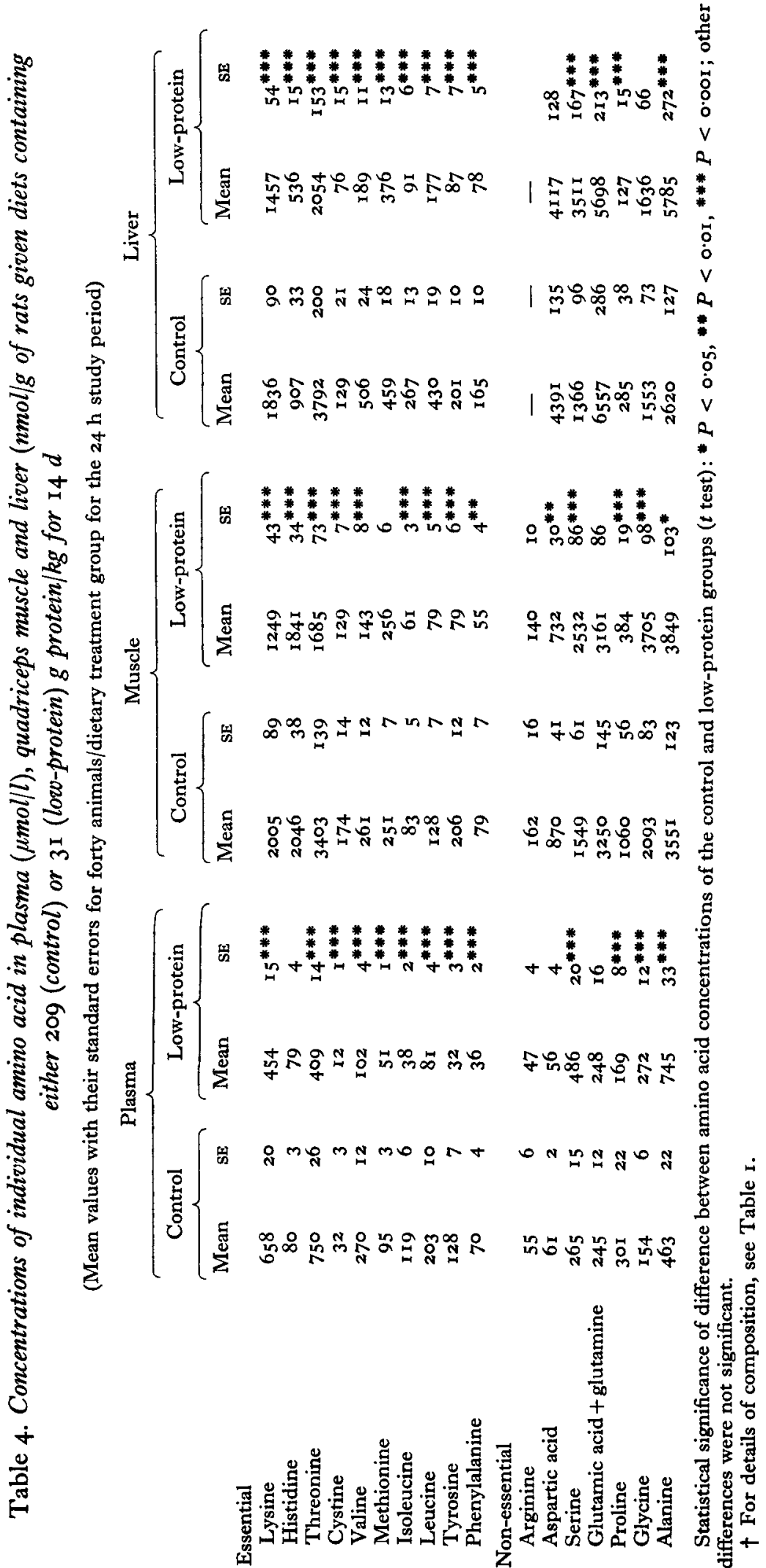


Table 5. The difference in the response to dietary treatment of the free amino acid patterns in liver and quadriceps muscle of rats given diets containing either 209 (control) or $3^{\mathrm{I}}$ (low-protein) $\mathrm{g}$ protein $/ \mathrm{kg}$ for $\mathrm{I} 4 \mathrm{~d}$

(Mean values for forty animals/dietary treatment group for the $24 \mathrm{~h}$ study period)

$\begin{array}{lccc}\text { Amino acid } & \begin{array}{l}\text { Response to low-protein diet* } \\ \text { (\% control concentrations) }\end{array} & \begin{array}{c}\text { Change in live } \\ \text { concentration } \\ \text { compared } \\ \text { change in mu } \\ \text { concentration }\end{array} \\ \text { Siver affected more than muscle } & \\ \text { Alanine } & +\mathrm{I} 57 & +64 & <0.001 \\ \text { Histidine } & +98 & +8 & <0.001 \\ \text { Valine } & -4 \mathrm{I} & -10 & <0.001 \\ \text { Methionine } & -63 & -45 & <0.01 \\ \text { Isoleucine } & -18 & +2 & <0.001 \\ \text { Leucine } & -66 & -26 & <0.001 \\ \text { Phenylalanine } & -59 & -38 & <0.01 \\ & -53 & -30 & <0.05\end{array}$

Both tissues affected to the same extent

$\begin{array}{lrrr}\text { Aspartic acid } & -6 & -16 & \text { NS } \\ \begin{array}{l}\text { Glutamic acid }+ \\ \text { glutamine }\end{array} & -13 & -3 & \text { NS } \\ \text { Proline } & -55 & -64 & \text { NS } \\ \text { Threonine } & -46 & -50 & \text { NS } \\ \text { Cystine } & -41 & -26 & \text { NS } \\ \text { Tyrosine } & -57 & -62 & \text { NS }\end{array}$

Muscle affected more than liver

$\begin{array}{lrrl}\text { Glycine } & +5 & +77 & <0.001 \\ \text { Lysine } & -21 & -3^{8} & <0.01\end{array}$

NS, not significant.

* For details of composition of diets, see Table $I$.

$\dagger$ The interaction term from an analysis of variance on the logarithms of the amino acid concentrations in the two tissues.

plasma from the low-protein group contained only $27.5 \%$ of the control concentrations of valine, and $14.4 \%$ of the control concentrations of tyrosine.

In the muscle of low-protein-fed animals only threonine, proline and tyrosine showed a mean reduction in concentration greater than $50 \%$ of control values, whereas in the liver, proline, valine, isoleucine, leucine, tyrosine and phenylalanine contents were all reduced by more than $50 \%$. The essential amino acids, histidine, valine, methionine, isoleucine, leucine and phenylalanine were all more reduced in content in liver than in muscle (Table 5). Likewise serine and alanine contents were both increased to a greater extent in liver than in muscle. Only lysine and glycine contents were more affected in muscle than liver.

\section{DISCUSSION}

Evidence has been provided which supports the assumptions of Whitehead \& Alleyne (1972), Lunn et al. (1973) and Rao (1974), that in the type of protein deficiency 
which leads to kwashiorkor the liver is disproportionately depleted of most essential amino acids, a situation likely to contribute to a reduced albumin synthesis. These results are in general agreement with those of Adibi, Modesto, Morse \& Amin (1973), in that the concentrations of essential amino acids are reduced both in liver and muscle to the same extent as in plasma, although they found that muscle appeared to be more affected than liver. There was, however, a major difference in the design of the two experiments. In the present study the protein content of the diet was such that no loss in weight occurred, which parallels the situation during the development of the early stages of protein malnutrition in Uganda (Rutishauser, 1974). In Adibi et al.'s (1973) study the animals were given a protein-free diet, and they lost weight throughout the study.

The exact influence of plasma and intracellular concentrations of amino acids on tissue protein synthesis is still undetermined; the literature on this topic has been extensively reviewed by Munro (1970). It is likely, however, that amino acid availability is one of the limiting factors, as is the concentration of the different amino acids relative to one another. For example, the greatly increased concentrations of alanine and serine in the malnourished rats must have diluted further the already depleted valine at the site of protein synthesis. In this study one would have expected that muscle protein synthesis, although limited, might not have been affected to quite the same extent as protein synthesis in the liver. Certainly when muscle wasting was induced in similarly low-protein-fed animals by cortisone administration (Lunn, Whitehead, Baker \& Austin, 1976), there was an increase in total free amino acid and protein contents of the liver, and the concentration of albumin in the plasma increased dramatically. It is obviously important in the interpretation of studies on malnutrition in animals to differentiate between those experiments in which bodyweight has been maintained, although growth might have been severely curtailed, and situations where there has been actual weight loss.

The present results have also confirmed the effects of protein malnutrition on the diurnal variations among the concentrations of essential amino acids in the plasma (Young et al. 1973). In addition the results indicated that similar changes also occur in the tissues. Even in normal animals, however, the significance of diurnal variations in free amino acid pools is not understood and thus the virtual eradication of this phenomenon among the essential amino acids in the low-protein-fed animals must be interpreted with care. It is generally considered that diurnal variations are produced by a number of interrelated factors including the pattern of food intake during the day, activity, and alterations in hormonal balance and enzyme activity. Whether the plasma fluctuations have any functional significance apparently depends on the relative abilities of different tissues to extract amino acids from the plasma (Wurtman, 1970). Protein synthesis too shows diurnal variations (Waterlow \& Alleyne, 1971) but whether the corresponding free amino acid changes are the cause or the product of this metabolic process is not known. The fact that amino acid patterns are subject to diurnal variation does emphasize the conclusions of Young et al. (1973) that interpretations of amino acid concentrations should not be based entirely on results obtained with fasting animals. 
One further point of importance arises from the present results. Although there were large changes in individual amino acid concentrations brought about by the lowprotein diet, total amino acid concentration was unaltered in the liver, and only a slight reduction occurred in the muscle. A measure of only total free-amino-nitrogen in these tissues would have given no indication of the extensive changes which had occurred in pool composition. Obviously in studies of this type it is necessary to measure the complete spectrum of amino acids to obtain an adequate indication of the extent of amino acid depletion in an organ.

The authors thank Mr S. A. Austin and Mr R. Hawkins for skilled technical assistance and Miss Heather Smith and Miss Marina Howlett for feeding the diets and looking after the animals.

\section{REFERENCES}

Adibi, S. A., Modesto, T. A., Morse, E. L. \& Amin, P. M. (1973). Am. F. Physiol. $225,408$.

Kirsch, R. E., Saunders, S. J., Frith, L., Wicht, S., Kelman, L. \& Brock, J. F. (1969). Am. F. clin. Nutr. 22, 1559 .

Lunn, P. G., Whitehead, R. G., Baker, B. A. \& Austin, S. (1976). Br. F. Nutr. In Press.

Lunn, P. G., Whitehead, R. G., Hay, R. W. \& Baker, B. A. (1973). Br. F. Nutr. 29, 399.

Munro, H. N. (1970). In Mammalian Protein Metabolism, vol. 4, p. 299 [H. N. Munro, editor]. New York and London: Academic Press.

Northam, B. E. \& Widdowson, G. M. (1967). Ass. clin. Biochemists Tech. Bull. no. I I.

Rao, K. S. J. (I974). Lancet i, 709 .

Rutishauser, I. H. E. (1974). E. Afr. med. F. 5x, 659.

Waterlow, J. C. \& Alleyne, G. A. O. (1971). Adv. Protein Chem. 25, 117.

Whitehead, R. G. \& Alleyne, G. A. O. (1972). Br. med. Bull. 28, 72.

Williams, M. A. \& Briggs, G. M. (1963). Am. F. clin. Nutr. 13, I 5.

Wurtman, R. J. (1970). In Mammalian Protein Metabolism, vol. 4, p. 445 [H. N. Munro, editor] New York and London: Academic Press.

Young, V. R., Vilaire, G., Newberne, P. M. \& Wilson, R. B. (1973). F. Nutr. 103, 720. 